\title{
Assessment of the mandibular incisive canal by panoramic radiograph and cone-beam computed tomography
}

\author{
Bozkurt Kubilay Işık ${ }^{\alpha}$, Melek Taşsöker ${ }^{\beta}$, Dilek Menziletoğlu ${ }^{\alpha}$, Sevgi Şener ${ }^{\beta}$, Alparslan Esen $^{\alpha}$
}

Selcuk Dent J, 2017; 4: 17-22

Başvuru Tarihi: 24 Ocak 2017 Yayına Kabul Tarihi: 10 Mart 2017

\section{ABSTRACT}

Assessment of the mandibular incisive canal by panoramic radiograph and cone-beam computed tomography

Background: This study aimed to evaluate the location and characteristics of mental foramen, anterior loop and mandibular incisive canal using cone beam computed tomography (CBCT) and digital panoramic radiograph (DPR).

Methods: 430 patients both DPRs and CBCTs scans for the location of mental foramen, anterior loop and mandibular incisive canal visibility were included in this retrospective study. All CBCTs were generated with a cone-beam volumetric tomography device.

Results: The mandibular incisive canal (MIC) at least one side in the interforaminal region was detected in $17.7 \%$ of panoramic images and $89.1 \%$ of CBCT images. There was statistically significant difference between two methods $(p=.000)$ in terms of MICs detection.

Conclusion: When planning a surgical operation between the mental foraminas, possibility of the presence of MIC should be taken into consideration. Besides, DPR is not a reliable technique in detecting MIC. In critical situations, use of CBCT is recommended.

\section{KEYWORDS}

Cone-beam computed tomography, mandible, mandibular nerve

The region between mental foramens has been considered as a safe zone for dental implants, symphyseal graft harvesting and genioplasty procedures, because no important anatomical structures are located here., ${ }^{1,2}$ However, the inferior alveolar canal may give terminal branches beyond the mental foramens which is named as the mandibular incisive canal (MIC). ${ }^{1}$ It has been advocated that some perioperative complications and postoperative morbidities can be attributed to this anatomical variation. ${ }^{1,3}$

\section{Öz}

Mandibuler insiziv kanalın panoramik radyograf ve konik ışınlı bilgisayarlı tomografi ile değerlendirilmesi

Amaç: Bu çalışmada, konik ışınlı bilgisayarlı tomografi (CBCT) ve digital panoramik radyograf (DPR) kullanarak mandibular insiziv kanalın, anterior loop'un ve mental foramenin karakteristiğini ve lokalizasyonunu incelemek amaçlanmıştır.

Gereç ve Yöntemler: Mandibuler insiziv kanal görünürlüğü, anterior loop ve mental foramenin lokalizasyonu için hem DPR hem de СВCT görüntüsü olan 430 hasta bu retrospektif çalışmaya dahil edildi. Bütün CBCT'ler konik ışınlı volumetrik tomografi cihazı ile alındı.

Bulgular: Panoramik görüntüde \%17.7 ve СBCT görüntüsünde \%89.1 interforaminal bölgede en az bir tarafta mandibular insiziv kanal (MIK) gözlemlenmiştir. MIK'ın fark edilmesinde kullanılan iki metod arasında istatistiksel olarak anlamlı bir fark bulunmuştur $(p=.000)$.

Sonuç: Mental foraminalar arasında cerrahi bir operasyon planlandığında MIC 'ın olma intimali düşünülmelidir. Bunun yanı sıra; DPR, MIC'ın araştııımasında güvenilir bir teknik değildir. Kritik durumlarda CBCT kullanımı tavsiye edilir.

\section{ANAHTAR KELIMELER}

Konik ışınlı bilgisayarlı tomografi, mandibula, mandibular sinir

Digital panoramic radiograph (DPR) is an extraoral radiographic technique that is widely used in oral and maxillofacial surgery. Although it is a reliable system for most cases, its accuracy in identifying the MIC is for most cases, its accuracy in identifying the MIC is limited. ${ }^{4} \quad$ Nowadays cone-beam computed tomography (CBCT) has gained popularity and in some branches, such as implant placement in critical regions, it has replaced with the DPR.

Our aim was to estimate the prevalence of MIC in Turkish population and evaluating the efficiency of DPR in detecting MIC by comparing with CBCT.

\footnotetext{
${ }^{\alpha}$ Necmettin Erbakan Üniversitesi Diş Hekimliği Fakültesi Ağız, Diş ve Çene Cerrahisi Anabilim Dalı, Konya

$\beta$ Necmettin Erbakan Üniversitesi Diş Hekimliği Fakültesi Ağı, Diş ve Çene Radyolojisi Anabilim Dalı, Konya
} 


\section{MATERIAL AND METHODS}

Local institutional research ethics committee approval was obtained for this retrospective study. We included 430 patients (245 females and 185 males, mean age 47.14 , ranging between 15 and 86 ) from whom both DPRs and CBCTs were taken between years 2014 and 2016. Indications were evaluation for orthognathic surgery and preparation for impacted teeth, dental implants planning, and orthodontic purposes. Exclusion criteria were as follows: presence of dental implants, syndromic patients, endocrine disturbances affecting craniofacial region, patients younger than 15, mandible fractures and distorted or blurred images.

All CBCTs were generated with a cone-beam volumetric tomography device (J. Morita, 3D Accuitomo 170, MFG Co., Kyoto, Japan) adjusted at $90 \mathrm{kVp}, 5 \mathrm{~mA}, 17.5$ seconds irradiation time, voxel size of $0.25 \mathrm{~mm}$ and field of view of $10 \times 10 \mathrm{~cm}$. Patients were placed in a horizontal position, stabilized with custom-made head bands and chin supports, and monitored to ensure that they remained motionless throughout the $17.5 \mathrm{sec}$ of scanning. The acquired images were reconstructed into multiple plane views (axial, panoramic and cross-sectional) for evaluation of the MIC. The course of the canal was located from the closure of the mental foramen up to obliteration of the MIC. Images of a radiolucent canal, within the trabecular bone, surrounded by a radiopaque cortical bone representing the canal walls, and extending to the anterior portion beyond the mental foramen were considered as being images of MIC (Figure1,2,3).

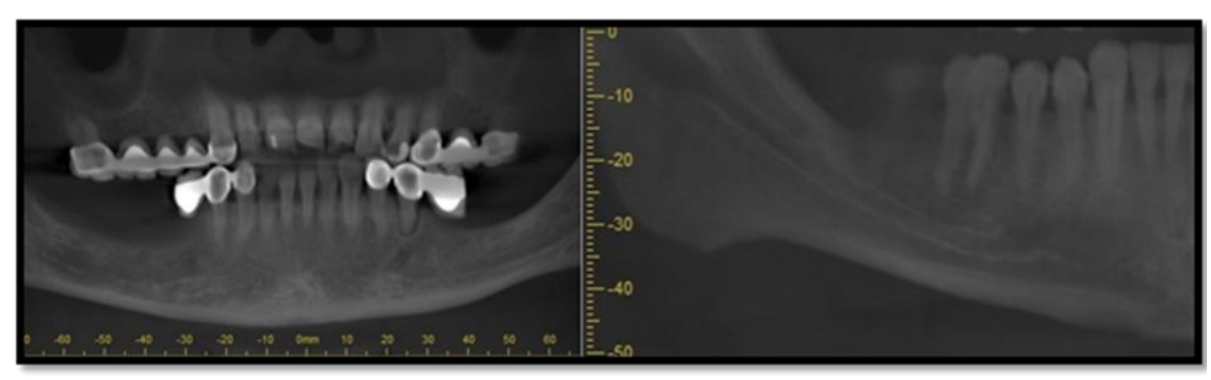

Figure 1.

Pseudopanoramic CBCT images of MIC

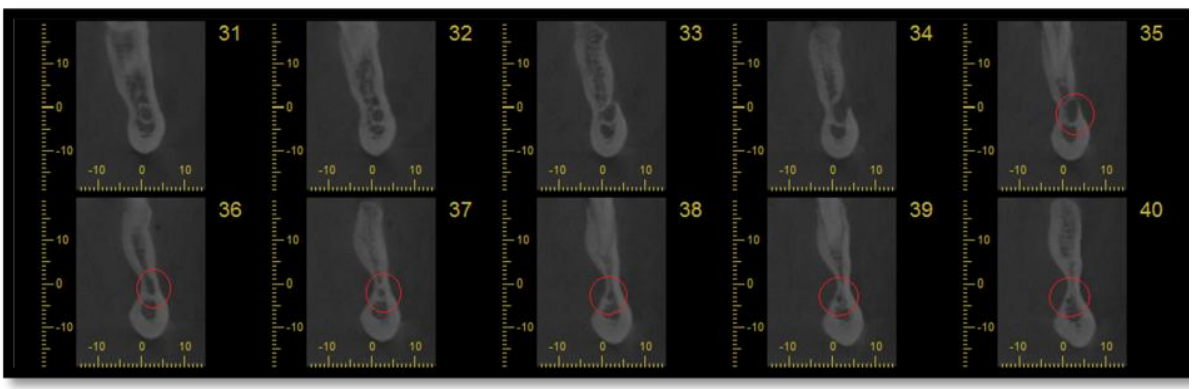

Figure 2.

Serial cross-sectional CBCT images presenting MIC between the sections 35 and 40

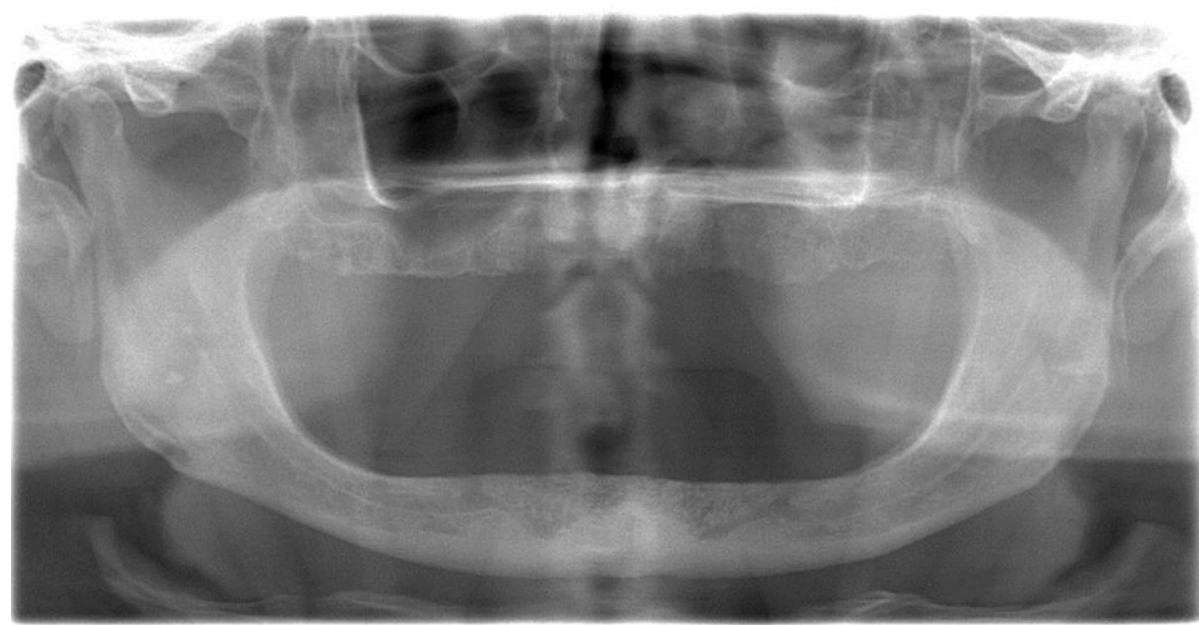

Figure 3.

Digital panoramic image of bilateral MIC 
DPRs were taken by using J MORITA (2D Veraviewpocs, MFG Co., Kyoto, Japan) machine with a tube voltage of $65 \mathrm{kV}$, tube current of $5 \mathrm{~mA}$ and exposure time of $14.8 \mathrm{sec}$. All the reconstructions and measurements were accomplished with the use of the i-Dixel software Ver. 2.0 (J. Morita MFG. Co.).

All radiographic and tomographic images were examined by two observers in a dark room and in the same computer (Intel ${ }^{\circ}$ Xeon ${ }^{\circledR}$ E52620, 2.0GHz; NVIDIA quadro 2000; 32" Dell T7600 workstation; $1280 \times 1024$ pixels screen resolution, 8GB memory, Microsoft Windows 7 operating system). Two oral and maxillofacial radiologists with 19 and 5 years of experience, respectively, evaluated the CBCT images. The observers performed re-examination in 2-week intervals to evaluate intraobserver variability. The examiners had to answer yes or no regarding the presence of MIC at least one side of the mandible in the images obtained with CBCT and DPR.

The incidence for MIC was calculated in percentages. Statistical analyses were carried out using the SPSS software (ver. 21.0; SPSS Inc., Chicago, IL, USA). Kappa statistics were applied for assessment of intra- and interobserver agreement. Chi-squared test was used for analysis of difference between DPR and CBCT method to identification of MICs. $p$ values less than 0.05 was considered to be significant. The kappa coefficient was interpreted as being poor (0), slight (0.01$0.20)$, fair $(0.21-0.40)$, moderate $(0.41-0.60)$, substantial (0.61-0.80), and almost perfect (0.81-1.0), according to Landis and Koch. ${ }^{5}$

\section{RESULTS}

The kappa statistics indicated an overall score of 0.83 for the interobserver agreement and a higher score (an average score of 0.92) for the intraobserver agreement for the visibility of MICs. Because of the intraobserver consistency was highest for observer 1 ; mean values of this observer's evaluations were used in analyses.

The MIC at least one side in the interforaminal region was detected in $17.7 \%$ of panoramic images and $89.1 \%$ of CBCT images. There was statistically significant difference between two methods $(p=.000)$ in terms of MICs detection.

\section{DISCUSSION}

Panoramic imaging, and later DPR as well, has gained much popularity since it was introduced. It visualizes the entire maxilla, mandible, temporomandibular joints and associated structures on a single film. It is used as a preliminary screening technique to evaluate the dentition, bone support, impacted teeth, and dental implant planning. However, it is subject to considerable and unpredictable geometric distortion and has relatively low spatial resolution. ${ }^{6}$ Most importantly, DPR is a $2 \mathrm{D}$ technique and cannot give a volumetric image of the region.

CBCT is generally used for diagnosis of pathologics, temporomandibular joint diseases, temporomandibular ankylosis, evaluation of maxiller sinus, jaw fracture, implant, maxillofacial trauma. ${ }^{7}$ CBCT is a radiographic imaging method that allows accurate, 3D imaging of the hard tissue. It provides sub-millimeter resolution with shorter scanning times and also it has got great dimensional accuracy (only about $2 \%$ magnification). ${ }^{8}$ Excellent imaging of the mandible and mandibular canal has been reported for $\mathrm{CBCT}$, along with a high accuracy of linear measurements and a low radiation dose and lower cost compared to multi-slice computed tomography. ${ }^{9}$ Because of the reliability of the CBCT in detecting anatomical hard tissue structures, we used it to estimate the prevalence of MIC in a Turkish population. Additionally, we aimed to evaluate the efficiency of DPR for the same goal.

Loss of anterior mandibular teeth is common and the anterior mandible has been considered an ideal implant site. ${ }^{1}$ Although some complications have been reported in this region that is widely used for rehabilitation of both anterior teeth loss with dental implants and implant supported complete overdentures. Lee et al ${ }^{10}$ described intraoperative complications resulting from injury to the structures within the MIC. Kutuk et al. ${ }^{11}$ and Abarca et al. ${ }^{3}$ reported that patients were complained of discomfort after implant surgery in the anterior mandible and they were attributed this to direct or indirect injury to the mandibular incisive nerve. Complications related to MIC have also been reported after autologous graft harvesting from this area. Neurosensory disturbances have been found to occur in the area confined to $5 \mathrm{~mm}$ anterior to the mental foramen, $5 \mathrm{~mm}$ below the tooth apex, and $5 \mathrm{~mm}$ above the lower border of the mandible. ${ }^{12}$ Nerve branches within the MIC have been suggested as the most likely reason for the paresthesia and reported to be neurapraxia when the chin bone was harvested. ${ }^{13}$ Instead of classically defined safety margins of $5 \mathrm{~mm}$, Pommer et al. ${ }^{12}$ have suggested new safety margins to protect the MIC: at least 8 $\mathrm{mm}$ below the tooth apices and a maximum harvest depth of $4 \mathrm{~mm}$. 
By using panoramic radiographs, some authors detected the MIC in $15 \%^{4}$ and others in $38.6 \%{ }^{1}$ of the images. The highest and lowest ratio was reported as $51.7 \%^{14}$ and $2,7 \%{ }^{15}$ respectively. We found the ratio of MIC in DPRs as $17.7 \%$ in at least one side. CBCT results suggest much more common prevalence of the MIC. In this study, we found the MIC in $89.1 \%$ of the cases but there are some reports which claim all CBCTs showed the MIC.,16 It has been also demonstrated that MIC was existed in all cadavers (Table 1). ${ }^{16}$

\section{Table 1.}

\section{The MIC studies in the literature}

\begin{tabular}{|c|c|c|c|c|}
\hline Author & Population & Year & Sample Size-Source & $\begin{array}{c}\text { Percentage } \\
(\%)\end{array}$ \\
\hline Jacobs et $\mathrm{al}^{18}$ & Belgium & 2002 & 230-Spiral CT & 93 \\
\hline Jacobs et $\mathrm{al}^{4}$ & Belgium & 2004 & 545-Panoramic radiographs & 15 \\
\hline Pires et $\mathrm{al}^{19}$ & USA & 2009 & $\begin{array}{c}\text { 89-Panoramic radiographs- } \\
\text { CBCT }\end{array}$ & 30621 \\
\hline Jalili et $\mathrm{al}^{14}$ & Iran & 2012 & 412-Panoramic radiographs & 51,7 \\
\hline $\begin{array}{l}\text { Romanos et } \\
\mathrm{al}^{15}\end{array}$ & USA & 2012 & 1045-Panoramic radiographs & 2,7 \\
\hline Orhan et $\mathrm{al}^{20}$ & Turkey & 2013 & 356-СВСТ & 91 \\
\hline Pereira et $\mathrm{al}^{21}$ & Spain & 2015 & 100-СВСТ & 100 \\
\hline Ramesh et $\mathrm{al}^{22}$ & Indian & 2015 & 120-СВСТ & 71,66 \\
\hline $\begin{array}{l}\text { Panjnoush et } \\
\mathrm{al}^{23}\end{array}$ & Iran & 2016 & 200-СBCT & 97,5 \\
\hline Present study & Turkey & 2016 & 430-DPRs andCBCTs & $17.7-89.1$ \\
\hline
\end{tabular}

Our results and the literature show that there is a clear difference between DPR and CBCT regarding the ability of detecting the MIC. Several factors can lead to this. First, DPRs inherently have a more distorted image in anterior mandible because of superimposition of anatomical structures, for example, cervical vertebrae ${ }^{19}$ that may make detecting the MIC more difficult. Second, the MIC is narrower and has less bony corticalization than inferior alveolar canal. ${ }^{24}$ It has also been reported ${ }^{17}$ that the diameter of the MIC decreased from its origin to end. These are obvious disadvantages in DPR technique. Additionally, some authors believe that the incisive nerve runs through the intramedullary spaces, and not within a bony canal, therefore, is not commonly detected by conventional radiography. ${ }^{21,25}$ In fact, the same limitation can be valid for СВCT as well due to the lack of well-defined MIC in the anterior part of the mandible. ${ }^{26}$ An incisive bundle can be seen as having complete, partial, or no cortical walls. ${ }^{17}$ Thus, it may be advocated that real incidence of the MIC might be even higher than the ratio found in CBCT images.

\section{CONCLUSION}

The MIC is common in Turkish population. We can even claim that existence of the MIC is "anatomically normal", it is not "an anatomical variation". When planning a surgical operation between the mental foraminas, possibility of the presence of MIC should be taken into consideration. Besides, DPR is not a reliable technique in detecting MIC. In critical situations, use of CBCT is recommended. 


\section{REFERENCES}

1. Kong N, Hui M, Miao F, Yuan H, Du Y, Chen N. Mandibular incisive canal in Han Chinese using cone beam computed tomography. Int J Oral Maxillofac Surg 2016;45(9):1142-6.

2. Raitz R, Shimura E, Chilvarquer I, Fenyo-Pereira M. Assessment of the mandibular incisive canal by panoramic radiograph and cone-beam computed tomography. Int J Dent 2014;2014:187085.

3. Abarca M, van Steenberghe D, Malevez C, De Ridder J, Jacobs R. Neurosensory disturbances after immediate loading of implants in the anterior mandible: an initial questionnaire approach followed by a psychophysical assessment. Clin Oral Investig 2006;10:269-77.

4. Jacobs R, Mraiwa $N$, Van Steenberghe $D$, Sanderink G, Quirynen M. Appearance of the mandibular incisive canal on panoramic radiographs. Surg Radiol Anat 2004;26:329-33.

5. Landis JR, Koch GG. The measurement of observer agreement for categorical data. Biometrics 1977;33:159-74.

6. Shah N, Bansal N, Logani A. Recent advances in imaging technologies in dentistry. World $\mathrm{J}$ Radiol 2014;6:794-807.

7. Harorlı A, Akgul M, Dagistan S.Diş Hekimliği Radyolojisi Kitabı; Atatürk Üniversitesi Yayınları; 2006. P.80-150.

8. Kumar M, Shanavas M, Sidappa A, Kiran M. Cone beam computed tomography - know its secrets. J Int Oral Health 2015;7:64-8.

9. Carrafiello G, Dizonno M, Colli V, Strocchi S, Pozzi Taubert S, et al. Comparative study of jaws with multislice computed tomography and cone-beam computed tomography. Radiol Med 2010;115: 600-11.

10.Lee CY, Yanagihara LC, Suzuki JB. Brisk, pulsatile bleeding from the anterior mandibular incisive canal during implant surgery: a case report and use of an active hemostatic matrix to terminate acute bleeding. Implant Dent 2012;21:368-73.

11.Kutuk N, Demirbas AE, Gonen ZB, Topan C, Kilic E, Etoz OA. Anterior mandibular zone safe for implants. J Craniofac Surg 2013; 24: 405-8.

12.Pommer B, Tepper G, Gahleitner A, Zechner W, Watzek G. New safety margins for chin bone harvesting based on the course of the mandibular incisive canal in CT. Clin Oral Implants Res 2008; 19:1312-6.

13.Joshi A. An investigation of post-operative morbidity following chin graft surgery. Br Dent $\mathrm{J}$ 2004;196: 215-8.
14.Jalili MR, Esmaeelinejad M, Bayat M, Aghdasi MM. Appearance of anatomical structures of mandible on panoramic radiographs in Iranian population. Acta Odontol Scand 2012;70:384-9.

15. Romanos GE, Papadimitriou DE, Royer K, Stefanova-Stephens N, Salwan R, Malmström H. The presence of the mandibular incisive canal: a panoramic radiographic examination. Implant Dent 2012;21:202-6.

16.Al-Ani O, Nambiar P, Ha KO, Ngeow WC. Safe zone for bone harvesting from the interforaminal region of the mandible. Clin Oral Implants Res 2013;24 Suppl A100:115-21.

17. Mardinger O, Chaushu G, Arensburg B, Taicher S, Kaffe I. Anatomic and radiologic course of the mandibular incisive canal. Surg Radiol Anat 2000; 22:157-61.

18.Jacobs R, Mraiwa N, vanSteenberghe D, Gijbels F, Quirynen M. Appearance, location, course, and morphology of the mandibular incisive canal: an assessment on spiral CT scan. Dentomaxillofac Radiol 2002;31:322-7.

19.Pires CA, Bissada NF, Becker JJ, Kanawati A, Landers MA. Mandibular incisive canal: cone beam computed tomography. Clin Implant Dent Relat Res 2012;14:67-73.

20.Orhan K, Icen M, Aksoy S, Ozan O, Berberoglu A. Cone-beam CT evaluation of morphology, location, and course of mandibular incisive canal: considerations for implant treatment. Oral Radiology 2014;3:64-75.

21.Pereira-Maciel $P$, Tavares-de-Sousa E, OliveiraSales MA. The mandibular incisive canal and its anatomical relationships: A cone beam computed tomography study. Med Oral Patol Oral Cir Bucal 2015;20:723-8.

22. Ramesh AS, Rijesh K, Sharma A, Prakash R, Kumar A, Karthik. The prevalence of mandibular incisive nerve canal and to evaluate its average location and dimension in Indian population. Journal of Pharmacy \& Bioallied Sciences 2015;7: 594-6.

23.Panjnoush M, Rabiee ZS, Kheirandish $Y$. Assessment of Location and Anatomical Characteristics of Mental Foramen, Anterior Loop and Mandibular Incisive Canal Using Cone Beam Computed Tomography. Journal of Dentistry (Tehran, Iran) 2016;13:126-32.

24. Mraiwa N, Jacobs R, Moerman P, Lambrichts I, van Steenberghe D, Quirynen M. Presence and course of the incisive canal in the human mandibular interforaminal region: two-dimensional imaging versus anatomical observations. Surg Radiol Anat 2003;25:416-23. 
25. Uchida Y, Noguchi N, Goto M, Yamashita Y, Hanihara $\mathrm{T}$, Takamori $\mathrm{H}$, et al. Measurement of anterior loop length for the mandibular canal and diameter of the mandibular incisive canal to avoid nerve damage when installing endosseous implants in the interforaminal region: a second attempt introducing cone beam computed tomography. J Oral Maxillofac Surg 2009;67:744-50.

26. Jacobs R, Lambrichts I, Liang X. Neurovascularization of the anterior jaw bones revisited using highresolution magnetic resonance imaging. Oral Surg Oral Med Oral Pathol Oral Radiol Endod 2007;103:683-93.

Corresponding Author:

Yrd.Doç.Dr. Dilek MENZiLETOĞLU

Necmettin Erbakan Üniversitesi

Diş Hekimliği Fakültesi

Ağız, Diş ve Çene Cerrahisi AD

Karaciğan Mah. Ankara Cad. No: 74

42050, Karatay, Konya

Phone: +90 3322200026

E-mail: dmenziletoglu@konya.edu.tr 